\title{
Endotracheal tube fastening device-related pressure necrosis of the upper lip
}

\author{
Dominik Greda, David Straka, Matthew Cooper, Russel Kahmke
}

Department of Head and Neck Surgery and Communication Sciences, Duke University Health System, Durham, North Carolina, USA

\section{Correspondence to} Dr Dominik Greda; dominik.greda@duke.edu

Accepted 4 February 2020

\section{DESCRIPTION}

A 73-year-old man with a history of coronary artery underwent four-vessel coronary artery bypass grafting at an outside hospital. On postoperative day (POD) 5, he developed acute respiratory failure in the setting of sepsis due to mediastinitis and required endotracheal intubation. His hospital course was further complicated by acute kidney injury, thrombogenic heparin-induced thrombocytopenia, bilateral pulmonary emboli and haemodynamic instability requiring multiple inotropes and vasopressors. The patient was transferred to our institution on POD 17 and underwent tracheostomy placement on POD 21 when the pressure injury to the upper lip was noted. Careful examination revealed advanced necrosis of the central portion of the upper lip vermilion with extension into the cutaneous and mucosal surfaces (figure 1A). A debridement of the necrotic tissue was performed, resulting in a full thickness central defect encompassing approximately $50 \%$ of the upper lip vermilion with preservation of the majority of philtrum (figure 1B). With wet-to-dry dressing changes, the wound bed healed with no need for additional debridements.

The patient's endotracheal tube (ETT) was secured with one of the commercially available ETT fasteners, AnchorFast (Hollister, Libertyville, Illinois, USA). Failure to detect early signs of the injury prevented initiation of earlier treatment of the pressure-induced wound and allowed progression to an advanced stage. Prolonged administrations of vasoactive medications and thrombogenic heparin-induced thrombocytopenia were also possible contributing factors. ${ }^{12}$ This patient eventually underwent upper lip reconstruction with bilateral reverse Karapandzic flap (figure 2). The reconstruction was successful in restoring the aesthetic balance of the central face and achieving
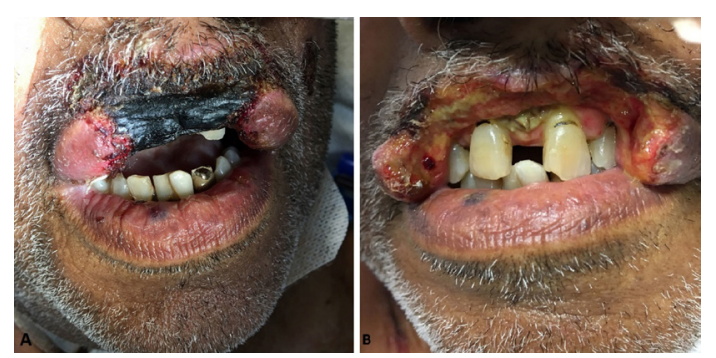

Figure 1 Pressure necrosis of the central portion of the upper lip vermilion as documented on the initial examination (A). Full thickness defect encompassing approximately $50 \%$ of the upper lip vermilion after debridement of the necrotic tissue (B).

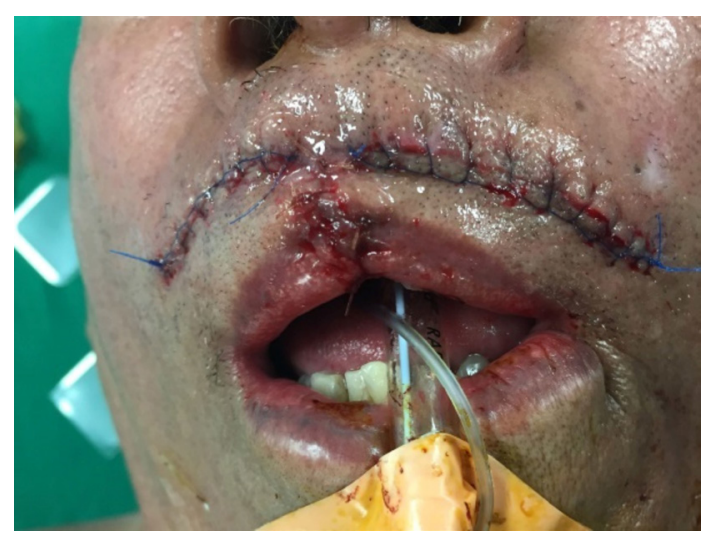

Figure 2 Immediate postoperative photograph of the upper lip reconstruction with bilateral reverse Karapandzic flap.

complete oral incompetence; however, significant tissue loss resulted in moderate microstomia. Outpatient speech therapy was critical in returning the patient's speech and deglutination functions to the baseline function.

Medical devices are a significant cause of preventable pressure injury in critically ill patients with nasogastric tubes and ETTs. The devices used to secure them are most commonly implicated. ${ }^{3-5}$ Endotracheal tube positioning devices are effective at preventing movement of the ETT and unplanned extubation ${ }^{6}$ while allowing efficient and easy repositioning. Prior studies, however, have not demonstrated consistent benefits in reducing injury to the mucosa or cutaneous tissue, ${ }^{5-7}$ with some studies reporting increased incidence of pressure injury when compared with ETT secured with adhesive or cloth tapes. ${ }^{8}$ This may be due to poor visualisation under the device to perform skin or cutaneous membrane assessment, improper fit or application, ${ }^{10} 11$ and increased pressure exerted on the face. ${ }^{5}$ Limited studies have suggested that implementation of standard protocols for prevention of ETT-related pressure injury and raising awareness among staff may have a potential role in reducing ETT fastening device-related pressure injuries. ${ }^{5} 12$ Quality improvement inquiry at our institution has led to several modifications of intensive care unit protocols: the ETT must be rotated every 6 hours; routine replacement of the fastening devices must occur every 5 days; and appropriate documentation, including assessment of the skin and mucous membranes, is required. More high-quality prospective studies, however, are needed to determine the optimal protocols to prevent this iatrogenic injury. 
- Endotracheal tubes (ETTs) and devices used to secure them can cause significant pressure injury to the mucous membranes of the oral cavity and cutaneous tissues of the face.

- Implementation of standard protocols for the prevention of ETT-related pressure injury and interventions raising awareness among staff may have a potential role in reducing the incidence and severity of injury.

- Assessment of the skin and mucous membranes in intubated patients should be clearly documented in the medical record.

Acknowledgements Special thank you to Dr C Scott Brown, MD, who performed the initial assessment and debridement of the necrotic lip; Dr Liana Puscas, MD, who supervised the reconstructive surgery.

Contributors DG: conception and design, drafting of the original manuscript, approval of the final manuscript. DS and RK: critical review and revision of the manuscript and approval of the final version. MC: provided details of the reconstructive surgery and postoperative rehabilitation, critical review and revision of the manuscript, and approval of the final version.

Funding The authors have not declared a specific grant for this research from any funding agency in the public, commercial or not-for-profit sectors.

Competing interests None declared.

Patient consent for publication Obtained.

\section{REFERENCES}

1 Alderden J, Whitney JD, Taylor SM, et al. Risk profile characteristics associated with outcomes of hospital-acquired pressure ulcers: a retrospective review. Crit Care Nurse 2011:31:30-43.

2 Tassava T, Warkentin TE. Non-injection-site necrotic skin lesions complicating postoperative heparin thromboprophylaxis. Am J Hematol 2015;90:747-50.

3 Hanonu S, A Prospective KA. Descriptive study to determine the rate and characteristics of and risk factors for the development of medical device-related pressure ulcers in intensive care units. Ostomy Wound Manage 2016;62:12-22.

4 Coyer FM, Stotts NA, Blackman VS. A prospective window into medical device-related pressure ulcers in intensive care. Int Wound J 2014;11:656-64.

5 Fisher DF, Chenelle CT, Marchese AD, et al. Comparison of commercial and noncommercial endotracheal tube-securing devices. Respir Care 2014;59:1315-23.

6 Gardner A, Hughes D, Cook R, et al. Best practice in stabilisation of oral endotracheal tubes: a systematic review. Aust Crit Care 2005;18:158-65.

7 Kaplow R, Bookbinder M. A comparison of four endotracheal tube holders. Heart Lung 1994;23:59-66.

8 Hampson J, Green C, Stewart J, et al. Impact of the introduction of an endotracheal tube attachment device on the incidence and severity of oral pressure injuries in the intensive care unit: a retrospective observational study. BMC Nurs 2018;17:2.

9 Levy H, Griego L. A comparative study of oral endotracheal tube securing methods. Chest 1993;104:1537-40.

10 Black JM, Cuddigan JE, Walko MA, et al. Medical device related pressure ulcers in hospitalized patients. Int Wound J 2010;7:358-65.

11 Apold J, Rydrych D. Preventing device-related pressure ulcers: using data to guide statewide change. J Nurs Care Qual 2012;27:28-34.

12 C Mussa C, Meksraityte E, Li J, et al. Factors associated with endotracheal tube related pressure injury. SM J Nurs 2018;4:1-6.

Copyright 2020 BMJ Publishing Group. All rights reserved. For permission to reuse any of this content visit

https://www.bmj.com/company/products-services/rights-and-licensing/permissions/

BMJ Case Report Fellows may re-use this article for personal use and teaching without any further permission.

Become a Fellow of BMJ Case Reports today and you can:

- Submit as many cases as you like

- Enjoy fast sympathetic peer review and rapid publication of accepted articles

- Access all the published articles

Re-use any of the published material for personal use and teaching without further permission

Customer Service

If you have any further queries about your subscription, please contact our customer services team on +44 (0) 2071111105 or via email at support@bmj.com.

Visit casereports.bmj.com for more articles like this and to become a Fellow 